\title{
Urogenital trichomoniasis in an Iraqi population
}

Nadham K. Mahdi'

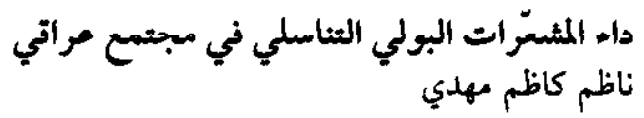

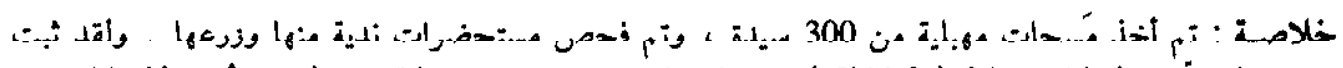

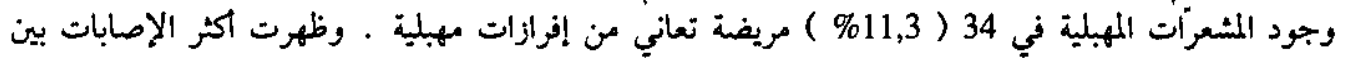

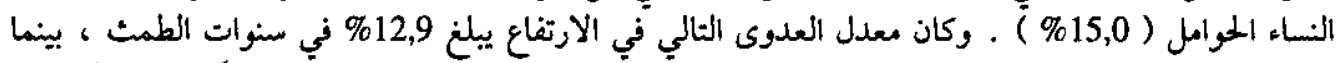

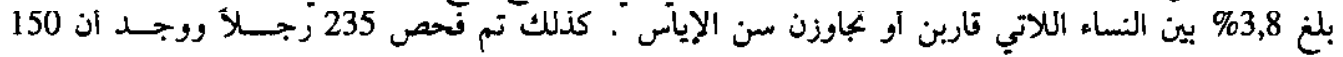

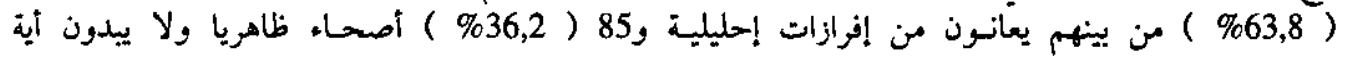

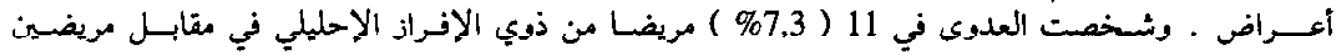

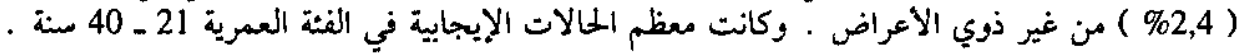

ABSTRACT Vaginal swabs were obtained from 300 famales and examined by the wet preparation and culture methods. Trichomonas vaginalis was identified in 34 female subjects $(11.3 \%)$ with vaginal discharge. Pregnant women showed the highest rate (15.0\%). The next highest infection rate $(12.9 \%)$ was noticed during the menstrual years. Women aged over 40 years showed a rate of $3.8 \%$. A total of 235 males were also investigated; $150(63.8 \%)$ presented with urethral discharge and $85(36.2 \%)$ were apparently healthy and asymptomatic. Among those with discharge, infection was identified in 11 subjects $(7.3 \%)$, against $2(2.4 \%)$ among the asymptomatic subjects. The majority of positive cases were in the age group $21-40$ years.

\section{La trichomonase urogénitale dans une population Iraquienne}

RESUME Des prélòvementes vaginaux par ́couvillon effectuós chez 300 femmes ont óté examinés par les méthodes de préparation à l'état frais et de culture. Trichomonas vaginalis a été identifié chez 34 patientes $(11,3 \%)$ ayant des écoulements vaginaux. Le taux le plus élevé $(15.0 \%)$ a été observé chez les fermmes enceintes. Tout de suite après. le taux d'infection le plus élevé (12,9\%) a été constaté chez les femmes réglées. Chez les femmes proches de la ménopause ou ménopausées,le taux était de $3,8 \%$. Des investigations ont également été effectuées chez 235 hommes; 150 d'entre eux $(63,8 \%)$ avaient des écoulements urétraux et 85 $(36.2 \%)$ étaient apparemment en bonne santé et ne présentaient aucun symptóme. Parmi ceux qui avaient des écoulements, l'infection a été identifiée chez 11 sujets $(7,3 \%)$ alors que, parmi les sujets ne présentant pas de symptômes, elle a été identifiée chez deux personnes $(2,4 \%)$. La majorité des cas positifs se situalent dans la tranche d'age de 21 à 40 ans.

\footnotetext{
'Department of Microblology, Collogo of Modicino, Univorsity of Dasra, Dasra, Iraq.
} 


\section{Introduction}

Genital trichomoniasis is a sexually transmitted disease affecting men and women. A frequency of $20 \%$ to $30 \%$ in sexual partners of infected women has been reported [1]. In women it causes vaginitis and cystitis, and in men it causes urethritis and prostatitis [2]. Sometimes Trichomonas vaginalis causes no symptoms at all in either sex. It is rarely reported in females before puberty and after menopause, but is common during the child-bearing years and peaks during pregnancy [3]. It causes up to $15 \%$ of cases of nongonococcal urethritis in men [2].

Men are commonly asymptomatic carriers of $T$. vaginalis. Symptoms may appear in chronic and acute forms [4]. Demonstration of this organism in men has always been difficult [5].

The present study was chosen because of the lack of information available on urogenital trichomoniasis in Iraq. Only three studies have been carried out among women, in Baghdad [6] and in Mosul [7] and Erbil [8] provinces where incidences of $19.5 \% .9 .6 \%$ and $10 \%$. respectively were recorded. There have been no studies concerning urogenital trichomoniasis among males and females.

\section{Subjects and methods}

Women. Vaginal swabs were obtained from 300 females and examined by the wet preparation and culture methods. All the women were attending the Obstetrics and Gynaecology Clinic at Al-Tahreer Hospital and private clinics in Basra province during a 12-month period (June 1992-June 1993). Cultures were carried out an Trichamanas medium No. 2 (Oxoid), incubated at $37^{\circ} \mathrm{C}$ and examined at 48 and 96 hours. Full information including age, gravidity, parity, complaint, marital status, family, social and past medical and obstetrical histories were reported.

Men. In private clinics in Basra, 235 males with or without urethral discharge were investigated. Samples were examined by the wet preparation and culture methods. Full medical history was taken for each subject. Healthy men were screened for urogenital trichomoniasis by urine examination. After centrifugation, the sediment was examined microscopically and inoculated into the Trichomonas medium. Specimens were incubated for 4 days at $37^{\circ} \mathrm{C}$, and examined for the presence of $T$. vaginalis.

\section{Results}

The overall incidence of $T$. vaginalis among women was found to be $11.3 \%$ (Table 1). One subject presenting to the clinic with positive trichomoniasis vaginalis was in childhood. Pregnant women showed the highest incidence (15.0\%). A high infection rate $(13.0 \%)$ was also evident during the menstrual years (11-40 years). Women near or post-menopause (over 40 years) showed an incidence of $3.8 \%$ (Table 2)

Table 1 Distribution of 300 females with urethral discharge in relation to menstrual htotory

\begin{tabular}{lrrr}
\hline $\begin{array}{l}\text { Menstrual } \\
\text { history }\end{array}$ & $\begin{array}{c}\text { No. } \\
\text { examined }\end{array}$ & $\begin{array}{c}\text { No. } \\
\text { positive }\end{array}$ & $\begin{array}{c}\% \\
\text { positive }\end{array}$ \\
\hline Pregnant & 80 & 12 & 15.0 \\
Non-pregnant & 103 & 13 & 12.6 \\
Lactating & 66 & 6 & 9.1 \\
Post-menopausal & 42 & 2 & 4.8 \\
Pre-puberty & 9 & 1 & 11.1 \\
Total & 300 & 34 & 11.3 \\
\hline
\end{tabular}


Table 2 Distribution of 300 females with urethral discharge by age and by marital status

\begin{tabular}{lrrr}
\hline $\begin{array}{l}\text { Age and } \\
\text { marital status }\end{array}$ & $\begin{array}{c}\text { No. } \\
\text { examined }\end{array}$ & $\begin{array}{c}\text { No. } \\
\text { positive }\end{array}$ & $\begin{array}{c}\% \\
\text { positive }\end{array}$ \\
\hline Age (years) & & & \\
$1-10$ & 9 & 1 & 11.1 \\
$11-20$ & 41 & 9 & 22.0 \\
$21-30$ & 105 & 15 & 14.3 \\
$31-40$ & 93 & 7 & 7.5 \\
over 40 & 52 & 2 & 3.8 \\
Marital status & & & \\
Married & 275 & 32 & 11.6 \\
Single & 17 & 1 & 5.9 \\
Widow & 8 & 1 & 12.5 \\
Total & 300 & 34 & 11.3 \\
\hline
\end{tabular}

Of 235 males investigated at the medical clinics visited, $150(63.8 \%)$ presented with urethral discharge and the remaining $85(36.2 \%)$ were apparently healthy and asymptomatic. Trichomonas vaginalis was identified in 11 subjects $(7.3 \%)$ of the symptomatic group and in two $(2.4 \%)$ of the asymptomatic group (Table 3 ). The majority of positive cases were in the age group $21-40$ years.

\section{Discussion}

The rates observed in this study are lower than those reported in various parts of the world, but they still represent an important level from the public health point of view. Examination of apparently healthy women was not possible because they refused to have vaginal swabs done due to the absence of a vaginal discharge complaint. Higher incidence has been reported in the United Kingdom, the United States and Poland. This variation may be explained by differences in hygiene and sanitation and in sexual relations before marriage.

Wet mount preparation has been the sole diagnostic test used in some studies of T. vaginalis epidemiology $[2,9,10]$ and therapy $[I I]$. In the present study, culture was the most sensitive diagnostic test for trichomoniasis. In no case was the vaginal wet mount preparation positive and the culture negative. However, having a less than desirable sensitivity, the wet preparation

Table 3 Analyete of males examined, by age, presence of urethral discherge and prosenee of T. vaghalls

\begin{tabular}{|c|c|c|c|c|c|c|}
\hline \multirow[t]{2}{*}{$\begin{array}{l}\text { Age } \\
\text { (years) }\end{array}$} & \multicolumn{2}{|c|}{$\begin{array}{l}\text { Men with urethral } \\
\text { discharge }\end{array}$} & \multicolumn{2}{|c|}{$\begin{array}{c}\text { Apparently } \\
\text { neaithy men }\end{array}$} & \multicolumn{2}{|c|}{ Total } \\
\hline & $\begin{array}{l}\text { No. } \\
\text { examined }\end{array}$ & $\begin{array}{l}\text { No }(\%) \\
\text { positive }\end{array}$ & $\begin{array}{l}\text { No. } \\
\text { examined }\end{array}$ & $\begin{array}{l}\text { No. }(\%) \\
\text { posltive }\end{array}$ & $\begin{array}{l}\text { No. } \\
\text { examined }\end{array}$ & $\begin{array}{l}\text { No. }(\%) \\
\text { positive }\end{array}$ \\
\hline $15-20$ & 25 & $2(8.0)$ & 16 & 0 & 41 & $2(4.9)$ \\
\hline $21-30$ & 62 & $4(6.5)$ & 24 & $1(4.2)$ & 86 & $5(5.8)$ \\
\hline $31-40$ & 51 & $4(7.8)$ & 35 & $1(2.9)$ & 86 & $5(5.8)$ \\
\hline over 40 & 12 & $1(8.3)$ & 10 & 0 & 22 & $1(4.5)$ \\
\hline Total & 150 & $11(7.3)$ & 85 & $2(2.4)$ & 235 & $13(5.5)$ \\
\hline
\end{tabular}

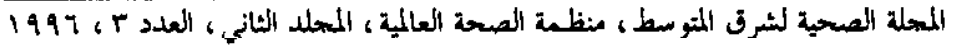


may be replaced in the near future by newer methods, such as the enzyme immunoassay or the direct fluorescent antibody test. Until the sensitivity, specificity and cost of these newer techniques are defined outside the research arena, the wet preparation and culture methods will remain the first line diagnostic tool $[12,13]$.

Pregnant women showed a higher infection rate $(15.0 \%)$. This may be attributed to the hypertrophy and hyperplasia of the vaginal epithelium, as well as to the increase of glycogen deposits in such cells, produced by high estrogen levels $[14,15]$. The presence of a relatively large number of positive cases among recently married females is clearly the responsibility of their husbands. In rare cases. the infection may be acquired through innocent means, such as toilet facilities, medical instruments or exchange of underclothing [13.16]. Other factors such as the susceptibility of the host, his physiological condition, the virulence and size of the inoculum, as well as social habits and hygiene conditions, might have an effect on the pathogenesis of $T$. vaginalis [16].

The chance of isolating $T$. vaginalis was higher when the patient presented with urethral discharge. Urine examination yielded low success for isolation [17]. However, $33 \%$ of men affected were sexual partners of women infected with the parasite.

This study gives a better understanding about the incidence of urogenital trichomoniasis. Clean instruments, attention to the associated problems of the genital and urinary tracts. collateral treatment of sexual partners, standard of living and education are of importance in controlling the disease among Iraqi women and men.

\section{References}

1. Brown MT. Trichonomiasis. Practitioner 1972, 209: 639-44.

2. Omer EE. Trichomoniasis in clinical practice. Postgraduate doctor, 1987, 10: 33-40.

3. Hira PR. Observations on T. vaginalis infection in Zambia. Tropical diseases bulletin, 1987, 75:6.

4. Honigberg BM. Trichomonads of importance in human medicine. In: Kreier JP, ed Parasitic protozoa. Vol II. New York, San Francisco and London, Academic Press, 1978:276-455.

5. Wilson A, Aekors JP. Urine eulturo for tho detection of $T$. vaginalis in men. British journal of venereal disease, 1980 , 56:46-8
6. Al-Shabandar N. Histopathological studies on Trichomonas. [M.Sc. Thesis]. Univorcity of Baghdad, Iraq, 1970.

7. Al-Mallan O, Al-Janabi BM. The incidence of Trichomonas vaginalis among selected groups of women In Mosul. Iraql medical journal, 1983, 31:29-33.

8. Kadir MA, Salehy AMS, Hammad EF. Studies on Trichomonas vaginalis in Erbil Teaching Hospital. Journal of the Faculty of Medicine, Baghdad 1988, 30:83-8.

9. Omer EE, Hag Ali M, Erwa HH. Study of sexually transmitted diseases in Sudanese women. Tropical doctor, 1980, 10:99-102.

10. Lazar A, Trichomonas vaginalis infection. Incidence with use of various contracep- 
tive methods. Journal of the Medical Society of New Jersey, 1970, 67:225-6.

11. Dykers JR, Single dose metronidazole for trichomonal vaginitis. New England journal of medicine, 1975, 293:23-4.

12. Lorsick JG, Kent HL. Trichomoniasis trends in diagnosis and management. American journal of obstotrics and gynocology, 1991, 165:1217-22.

13. Sparks JM. Vaginitis. Journal of reproductive medicine, 1991, 36:745-52.

14. Jones HW, Jones GS. Gynecology, 3rd ed. New York, Williams and Wilkins, 1982.
15. Studd J. Progress in obstetrics and gynaecology. Vol 10, London and New York, Churchill. Livingstone, 1993.

16. Belding DL. Textbook of parasitology. 3rd ed. New York. Appleton-Century-Crofts. 1965.

17. Lumsden WHR, Robertson DHH, MoNoillage GJC. Isolation, oultivation, low temperature preservation and infectivity titration of $T$. vaginalis. British journal of venereal disease, 1966. 42:145-54.

\section{STD control programmes to be strengthened}

Further efforts should be made to strengthen the national sexually transmlttcd discases (STD) control programmes in the Eastern Mediterranean Region of WHO. This was the conclusion reached, in the light of signiflcant incidence and prevalence of STD In the Reglon, by national STD experts at the second Intercountry Workshop on Control of STD whlch was held in Islamabad, Pakistan from 26 to 28 Movember 1996. The workshop was organized by WHO's Reglonal Offlce for the Eastern Mediterranean in collaboration with the Government of Paklstan and was attended by participants from Djlbouti, Egypt, Islamic Republlc of Iran, Iraq, Jordan, Lebanon, Pakistan, Sudan, Syrian Arab Republlc and Republlc of Yemen as well as by who staff from the headquarters, regional and country offlces and UMAIDS staff.

In his message to the workshop, the Regional Director Dr Hussein A. Gezairy stressed the need to give priority to prevention of STD and to syndromic ap- proach to STD case management, which provides adequate and complete care. In order to reduce morbidity, compllcations and sequelae arlsing from STD, efforts must be made to see that STD patlents seek care early and complete the treatment, Dr. Gezalry sald. He assured the Member States of WHO's continued efforts to provide technical and financial support.

In his opening address, Mr. Zaheer Sajad, Secretary, Ministry of Health, Government of Pakistan underscored the problem of STD as one of worldwide and major significance in terms of health, economk and soclal consequences that require priority management attention. Because of the substantlal magnitude of the STO problem In Pakistan, Mr. Sajjad added, a number of measures have been taken for STD control there including training, distribution of case management guidelines and of educational materlal and launching of electronic medla campalgn. 